medRxiv preprint doi: https://doi.org/10.1101/2021.05.25.21257614; this version posted May 27, 2021. The copyright holder for this preprint (which was not certified by peer review) is the author/funder, who has granted medRxiv a license to display the preprint in perpetuity.

All rights reserved. No reuse allowed without permission.

\title{
Serum antibodies to surface proteins of Chlamydia trachomatis as candidate biomarkers of disease: Results from the Baltimore Chlamydia Adolescent/Young Adult Reproductive Management (CHARM) cohort.
}

Patricia X. Marques $\mathrm{PhD}^{\mathrm{a}}$, Handan Wand $\mathrm{PhD}^{\mathrm{b}}$, Melissa Nandy $\mathrm{MSc}^{\mathrm{c}}$, Chun Tan $\mathrm{PhD}^{\mathrm{a}}$, Huizhong Shou BS ${ }^{a}$, Mishka Terplan $\mathrm{PhD}^{\mathrm{d}}$, Katrina Mark MD ${ }^{\mathrm{e}}$, Rebecca M. Brotman $\mathrm{PhD}^{c}$, David P. Wilson $\mathrm{PhD}^{f}$, Jacques Ravel $\mathrm{PhD}^{g, c}$, Ru-ching Hsia $\mathrm{PhD}^{\mathrm{h}}$ and Patrik $\mathrm{M}$. $\underline{B a v o i l ~} \mathrm{PhD}^{\mathrm{a}}$

Depts of aMicrobial Pathogenesis, ${ }^{\mathrm{d} O b s t e t r i c s ~ \& ~ G y n e c o l o g y, ~}{ }^{e}$ Pediatrics and 9Microbiology and Immunology, 'Institute for Genome Science, and hElectron Microscopy Core Imaging Facility, University of Maryland, Baltimore, Maryland, USA; ${ }^{\mathrm{b}}$ The Kirby Institute, University of New South Wales, Sydney, Australia; 'The Burnet Institute, Melbourne, Australia

Corresponding author: Patrik M Bavoil, Dept of Microbial Pathogenesis, University of Maryland School of Dentistry, 650 W. Baltimore St., Baltimore, MD 21201. Tel: 410706 6789; Fax: 410706 0865; e-mail: pbavoil@umaryland.edu.

Word counts: Summary: 20; Abstract: 240; Text: 2,719

Number of references: 33; Number of figures: 2; Number of tables: 4

\section{Conflicts of Interest and Source of Funding}

The authors do not have a commercial or other association that might pose a conflict of interest (e.g., pharmaceutical stock ownership, consultancy, advisory board membership, relevant patents, or research funding).

Research reported in this publication was supported by the National Institute of Allergy and Infectious Diseases of the National Institutes of Health under award number U19AI084044. The content is solely the responsibility of the authors and does not necessarily represent the official views of the National Institutes of Health

\section{Acknowledgements}

The contributions of Esther Colinetti, Nyaradzo Longinaker, Anup Mahurkar and Dr. Ligia Peralta to the development of the CHARM cohort are gratefully acknowledged. 
medRxiv preprint doi: https://doi.org/10.1101/2021.05.25.21257614; this version posted May 27, 2021. The copyright holder for this preprint (which was not certified by peer review) is the author/funder, who has granted medRxiv a license to display the preprint in perpetuity.

\section{Short Summary}

Serological analysis of the CHARM cohort shows an association of the serum antibody response against $\mathrm{OmcB}$ and pelvic inflammatory disease.

\section{Abstract}

Background: We previously observed that the nine-member family of autotransported polymorphic membrane proteins (Pmps) of Chlamydia trachomatis is variably expressed in cell culture. Additionally, C. trachomatis-infected patients display variable Pmp-specific serum antibody profiles indirectly suggesting expression of unique Pmp profiles is an adaptive response to host-specific stimuli during infection. Here, we propose that the host response to Pmps and other outer surface proteins may correlate with disease severity. Methods: This study tests this hypothesis using an ELISA that measures serum IgG antibodies specific for the nine C. trachomatis Pmp subtypes and four immunodominant antigens (MOMP, OmcB, GroEL, ClpP) in 265 participants of the Chlamydia Adolescent/Young Adult Reproductive Management (CHARM) cohort.

Results: More C. trachomatis-infected females displayed high Pmp-specific antibody levels (cut-off Indexes) than males (35.9-40.7\% of females vs. $24.2-30.0 \%$ of males), with statistical significance for $\mathrm{PmpC}, \mathrm{F}$ and $\mathrm{H}(\mathrm{P}<0.05)$. Differences in $\mathrm{Pmp}$-specific antibody profiles were not observed between C. trachomatis-infected females with a clinical diagnosis of pelvic inflammatory disease (PID) and those without. However, a statistically significant association between high levels of OmcB-specific antibody and a PID diagnosis $(P<0.05)$ was observed. 
medRxiv preprint doi: https://doi.org/10.1101/2021.05.25.21257614; this version posted May 27, 2021. The copyright holder for this preprint (which was not certified by peer review) is the author/funder, who has granted medRxiv a license to display the preprint in perpetuity.

All rights reserved. No reuse allowed without permission.

54 Conclusions: Using antibody levels as an indirect measure of antigen expression, our

55 results suggest that gender- and/or site-specific (cervix in females vs. urethra in males)

56 stimuli control pmp expression in infected patients. They also support the possible

57 existence of immune biomarkers of chlamydial infection associated with disease and

58 underline the need for high resolution screening in human serum.

59

60 Keywords: Chlamydia trachomatis, polymorphic membrane proteins, surface proteins,

61 serology, ELISA, antibodies, pelvic inflammatory disease

62 
medRxiv preprint doi: https://doi.org/10.1101/2021.05.25.21257614; this version posted May 27, 2021. The copyright holder for this preprint (which was not certified by peer review) is the author/funder, who has granted medRxiv a license to display the preprint in perpetuity.

\section{INTRODUCTION}

In 2018, more than 1.8 million cases of sexually transmitted Chlamydia trachomatis infection in the United States were reported to the Centers for Disease Control and Prevention (1). Chlamydial infections, which are often asymptomatic, can lead to pelvic inflammatory disease (PID), a precursor of female infertility, ectopic pregnancy, and chronic pelvic pain in $10-20 \%$ of infected women. Screening for C. trachomatis using nucleic acid amplification tests followed by treatment, can reduce the incidence of PID by as much as $60 \%(2)$, suggesting that detection of an active chlamydial infection is an effective means of reducing future sequelae. To fully control chlamydial disease however, host or chlamydial biomarkers that can discriminate between different clinical outcomes early in, or during, infection remain highly desirable.

A panoply of secreted and/or surface proteins of $C$. trachomatis are thought to act early in infection (3-6) as adhesins and/or invasins. These include the elementary body (EB)-specific cysteine-rich outer membrane complex protein OmcB (5), the major outer membrane protein MOMP (OmpA) (7), and members of the polymorphic membrane protein family (Pmps) (8). The late-expressed cysteine-rich protein OmcB was previously suggested as a candidate adhesin for C. trachomatis (9), Chlamydia caviae (3), and more recently for Chlamydia pneumoniae (5). MOMP displays sequence-variable domains defining 17 serovars categorized according to tissue tropism (A-C, ocular; D-K, urogenital; L1-L3, inguinal lymph nodes), and was also proposed to function as an adhesin for $C$. trachomatis (10). The 9-member pmp gene family of C. trachomatis (Pmp subtypes A-l; (11)) is predicted to be associated with tissue tropism (12). C. trachomatis PmpD-specific antibody has been shown to dramatically reduce infection in vitro $(6,13)$. These properties 
medRxiv preprint doi: https://doi.org/10.1101/2021.05.25.21257614; this version posted May 27, 2021. The copyright holder for this preprint (which was not certified by peer review) is the author/funder, who has granted medRxiv a license to display the preprint in perpetuity.

All rights reserved. No reuse allowed without permission.

and the observed on/off switching of expression of the Pmps in cell culture $(8,14)$ suggest that production of a specific Pmp subtype(s) may be required and/or selected for at different sites or stages of infection. Consistent with variable expression in cell culture, we have previously shown that all $C$. trachomatis-infected patients mount a strong serologic response against different subsets of Pmps (15) with a suggested correlation between disease (PID) and Pmpl antibody titer $(15,16)$.

The presence at the chlamydial surface of specific OmcB and MOMP types combined with the expression of diverse PmpA-I profiles may provide the outer coat diversity that is necessary for adherence to, internalization by and colonization of diverse mucosal sites. Since sites of infection may be associated with a spectrum of pathologies ranging from none to severe, we further propose that distinct outer surface protein profiles may also correlate with disease severity. Here we indirectly test these two linked hypotheses using an antibody capture ELISA to evaluate the host response to OmcB and MOMP, and as a surrogate for the expression of specific Pmp subtypes. We use serum samples from participants in the Chlamydia Adolescent/Young Adult Reproductive Management (CHARM) cohort enrolled in the Baltimore, Maryland area. To address site/gender specific expression, sera from C. trachomatis-infected men and women are compared. To address the possible link with disease severity, sera from women with a lower genital tract $C$. trachomatis infection and a reported PID diagnosis are compared with those without a PID diagnosis. Because of their previously reported association with disease in other studies, the C. trachomatis Heat Shock Protein GroEL (Hsp60) (17-19) and the Caseinolytic protease P (ClpP) (19) are also included. 
medRxiv preprint doi: https://doi.org/10.1101/2021.05.25.21257614; this version posted May 27, 2021. The copyright holder for this preprint (which was not certified by peer review) is the author/funder, who has granted medRxiv a license to display the preprint in perpetuity.

\section{METHODS}

\section{CHARM cohort}

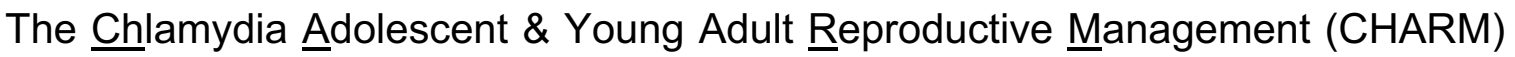
cohort consists of 276 Chlamydia trachomatis-infected men and women recruited between September 2010 and December 2013 in the Baltimore area (Table 1). CHARM inclusion and exclusion criteria, informed consent, treatment, data and specimens collected at entry and at intervals, follow-up activities, and statistical analyses were published independently (20). CHARM (HP-00042320) was reviewed and approved by the Institutional Review Board of the University of Maryland Baltimore. For the purpose of this study, blood was collected without additives at enrollment and prior to antibiotic treatment. After centrifugation, serum samples were stored at $-20^{\circ} \mathrm{C}$ until analyzed. PID diagnosis was based on the minimum clinical criteria (cervical motion tenderness, uterine tenderness or adnexal tenderness) as set by the Centers for Disease Control and Prevention (21).

\section{Recombinant polypeptides}

The predicted passenger domains of PmpC, D, E, F, H and I, smaller fragments of PmpA (pmpA-F2), PmpB (pmpB-F1 and pmpB-F2) and PmpG (Figure 1) (15), rMOMP rGroEL, rOmcB and rClpP (from C. trachomatis serovar D; kindly provided by $\mathrm{Dr}$. Guangming Zhong) were expressed in E. coli BL21(DE3) and purified as indicated in Table S1 (Supplemental Digital Content 1 listing characteristics and purification conditions of the recombinant polypeptides). 
medRxiv preprint doi: https://doi.org/10.1101/2021.05.25.21257614; this version posted May 27, 2021. The copyright holder for this preprint (which was not certified by peer review) is the author/funder, who has granted medRxiv a license to display the preprint in perpetuity.

All rights reserved. No reuse allowed without permission.

131 Insoluble polypeptides (all except rGroEL) were solubilized overnight at $42^{\circ} \mathrm{C}$ in $8 \mathrm{M}$

132 urea/10 mg/ml Octyl beta-D-glucopyranoside (OGP) in buffer (50 mM Tris- $\mathrm{HCl}, \mathrm{pH} \mathrm{8/1}$

133 mM EDTA/1 mM DTT), dialyzed against 0.01\% OGP and affinity purified (Table S1, in

134 Supplemental Digital Content 1).

Supplemental Digital Content 1, which shows Expression and purification of all the recombinant proteins and peptides used in this study).

ELISA purified recombinant polypeptides (see Table S2, in Supplemental Digital Content 1) were

144 incubated overnight at $4^{\circ} \mathrm{C}$, washed with PBS-T and blocked with $2.5 \%$ milk. ELISA was performed as described (23) using diluted CHARM sera (Table S2, Supplemental Digital Content 1) and goat anti-human IgG peroxidase labeled antibody (1:2000 dilution; 100 $\mu \mathrm{l} /$ well; KPL, Inc.). Results were read in a Beckman DTX 880 plate reader (Beckman Coulter, Inc.) at 450 and $620 \mathrm{~nm}$ (background). immunoblot analysis and densitometry (15) (not shown), thus supporting the validity of

151 results obtained by either method. ELISA results generated with GST•tagged and 152 His •tagged OmcB were positively correlated $(p<0.001$; see Figure S2, in Supplemental 
medRxiv preprint doi: https://doi.org/10.1101/2021.05.25.21257614; this version posted May 27, 2021. The copyright holder for this preprint (which was not certified by peer review) is the author/funder, who has granted medRxiv a license to display the preprint in perpetuity.

All rights reserved. No reuse allowed without permission.

153 Digital Content 1, a graphic of the correlation between G-OmcB and $\mathrm{H}-\mathrm{OmcB}$ ), further

154 validating the ELISA.

155

156 Statistical analysis

157 Chi-squared test was used to compare the demographic, sexual behavior and

158 biological factors of the study groups. Median and inter-quartile ranges were used to

159 describe continuous variables. A non-parametric test was used to compare the median

160 by gender.

161

Antibody levels defined as the cut-off Indexes for rPmpA to I, rClpP, rHsp60,

162 rMOMP, rOmcB and C. trachomatis purified EBs were used as categorical variables and

163 split into tertiles. The first tertile cut-point represented the lower, while the third tertile

164 represented the higher cut-off indexes. Logistic regression models were then used to

165 determine the association between cut-off indexes in the first and third tertiles

166 (highest/lowest) and PID diagnosis (outcome). Unadjusted and adjusted Odds Ratios

167 (ORs) and their 95\% confidence intervals (Cls) were calculated. In adjusted analysis,

168 results were presented after accounting for potential confounding effects of age,

169 Trichomonas vaginalis infection and a diagnosis of bacterial vaginosis (BV) based on

170 Amsel's criteria (24).

171 All analyses were performed using Stata 12.0 (College Station). 
medRxiv preprint doi: https://doi.org/10.1101/2021.05.25.21257614; this version posted May 27, 2021. The copyright holder for this preprint (which was not certified by peer review) is the author/funder, who has granted medRxiv a license to display the preprint in perpetuity.

\section{RESULTS}

174

175

176

177

178

179

180

181

182

183

184

185

186

187

188

189

190

191

192

193

194

195

\section{Demographics and sexual behavior in the CHARM cohort}

A total of 265 participants (120 males, $45.3 \%$ and 145 females, $54.7 \%$ ) of the CHARM cohort were included in the study. The overall median age of the study population was 19.5 years old (IQR: 17-21). Males were more likely to be older (median: 20.2 years, IQR: 18-22) compared to women (18.9 years, IQR: $17-21$ respectively) $(p=0.0047)$. Table 1 compares demographic data, sexual behavior, sexual history and past and current diagnosis of sexually transmitted infections (STIs) in men and women of the CHARM cohort (20). Most of the study population reported having first vaginal intercourse before age 13 years (84.2\%). Females were more likely to report a sexual debut before age 13 years $(86.7$ females vs. $77.5 \%$, males, $p=0.007)$. The majority of the participants $(64.5 \%)$ reported having 6 or more lifetime sexual partners. Male participants were more likely than females to report $6+$ sexual partners $(53.1 \%$ females vs. $78.3 \%$ males, $p<0.001)$. There were no significant differences reported for receptive oral or anal sex based on gender. Of the 145 CHARM female participants whose samples were analyzed by ELISA, $126(86.9 \%)$ were heterosexual, one (0.7\%) was homosexual and $18(12.4 \%)$ were bisexual. Thirty seven (25.5\%) reported receptive anal sex. Of the CHARM 120 male participants, $105(87.5 \%)$ were heterosexual, 9 (7.5\%) were homosexual and $6(5 \%)$ bisexual. Thirteen (10.8\%) reported receptive anal sex. Overall, $12.0 \%$ of the participants reported condom use in the last 3 months and females were significantly less likely to report having sex with partners who used condoms compared to males $(7.6 \%$ females vs. $17.5 \%$ males, $\mathrm{p}=0.014)$. Most of the CHARM participants were African Americans or of Hispanic/Latino ethnicity. 
medRxiv preprint doi: https://doi.org/10.1101/2021.05.25.21257614; this version posted May 27, 2021. The copyright holder for this preprint (which was not certified by peer review) is the author/funder, who has granted medRxiv a license to display the preprint in perpetuity.

Factors associated with pelvic inflammatory disease (PID) in the females of the between a PID diagnosis with various demographic and sexual risk factors. Participants self-reporting previous $T$. vaginalis infection (OR: $2.79,95 \% \mathrm{Cl}$ : $1.15-6.80$, pvalue $=0.0230 .025)$, and previous PID (OR: 19.82, 95\% Cl: $2.23-176.52$, p-value=0.007) were more likely to be diagnosed with PID at study entry.

The serum Pmp-specific antibody profile of $C$. trachomatis-infected CHARM

C. trachomatis and C. pneumoniae purified EBs and recombinant antigen ELISA were used to analyze serum antibodies (lgG) of 265 patients (145153 females and 120 males) from the CHARM cohort. Most participants had an antibody response against $\mathrm{H}$ rOmcB, H-rPmpC, G-rHsp60, and H-rPmpl with sensitivity above 85\% (Table S3, EBs was very low with only 3 samples (1.1\%) with slightly elevated antibody levels.

215 gender was investigated. Overall, when compared to males, a higher proportion of 216 females were in the top tertile across all Pmps (35.9-40.7\% for females vs. 24.2-30.0\% 217 for males; Table 3). Significant gender differences were observed for rPmps subtypes $\mathrm{H}$ 218 rPmpC-N (39.3\% vs. 25.8\%, p=0.001 for females and males respectively), H-rPmpF-N 
medRxiv preprint doi: https://doi.org/10.1101/2021.05.25.21257614; this version posted May 27, 2021. The copyright holder for this preprint (which was not certified by peer review) is the author/funder, who has granted medRxiv a license to display the preprint in perpetuity.

(36.6\% vs $29.2 \%, p=0.020)$ and $\mathrm{rPmpH}-\mathrm{N}(40.7 \%$ vs $24.2 \%, \mathrm{p}=0.018)$. Trending statistical significance was observed for G-rPmpA-F2 (39.3\% vs. $25.8 \%, p=0.068)$, and H-rPmpE$\mathrm{N}(39.3 \%$ vs. $25.8 \%, p=0.063)$. For $\mathrm{G}-\mathrm{MOMP}$, a significant proportion of males were in the lower tertile when compared to females $(26.2 \%$ vs. $42.5 \%, p=0.011)$. Gender-based differences were not detected for other recombinant peptides.

The serum OmcB-specific antibody response is associated with a clinical diagnosis of pelvic inflammatory disease (PID) in C. trachomatis-infected female CHARM participants

High antibody levels against H-rOmcB (Figure 2; Table 4 and see S4, in Supplemental Digital Content 1, showing associations between factors (in tertiles) associated with PID diagnosis with tertiles calculated only for females; OR: $2.31,95 \% \mathrm{Cl}$ : 0.72-7.46, $p=0.160$ and OR: $4.22,95 \% \mathrm{Cl}: 1.37-13.01, p=0.012$, respectively) were significantly associated with a clinical diagnosis of PID. Similar results were obtained for G-rOmcB (Figure 2; Tables 4 and S4) associated with PID diagnosis with tertiles calculated only for females; OR: $2.58,95 \% \mathrm{Cl}: 0.87-7.63, \mathrm{p}=0.087 /$ second vs. first tertile, OR: $2.56,95 \% \mathrm{Cl}: 0.86-7.65, \mathrm{p}=0.091 /$ third vs. first tertile).

In contrast, antibodies to the other tested antigens were not individually associated with PID with any statistical significance. Antibody levels for the second and third tertiles were almost identical for Hsp60 and MOMP (Figure 2.). Similarly, antibody levels against each of the Pmp subtypes were not significantly associated with PID, although the response to $\mathrm{H}-\mathrm{rPmpl}$ was borderline significant (Figure 2; OR: 2.52, 95\% Cl: 0.89-7.11, $p=0.075 /$ first vs. second tertile). Interestingly, however, antibody levels against 8 of the 9 
medRxiv preprint doi: https://doi.org/10.1101/2021.05.25.21257614; this version posted May 27, 2021. The copyright holder for this preprint (which was not certified by peer review) is the author/funder, who has granted medRxiv a license to display the preprint in perpetuity. All rights reserved. No reuse allowed without permission.

242 rPmp subtypes (all but $\mathrm{H}-\mathrm{rPmpF}$ ) were slightly higher in women without a clinical

243 diagnosis of PID, although none reached statistical significance individually. This

244 suggests a global negative association of antibodies against the Pmp family and upper

245 genital tract disease. 
medRxiv preprint doi: https://doi.org/10.1101/2021.05.25.21257614; this version posted May 27, 2021. The copyright holder for this preprint (which was not certified by peer review) is the author/funder, who has granted medRxiv a license to display the preprint in perpetuity.

\section{DISCUSSION AND CONCLUSIONS}

An ELISA was developed to measure antibody levels against recombinant polypeptides derived from the 9 C. trachomatis Pmps, the EB-specific OmcB, MOMP, ClpP, and the stress response protein GroEL, in 265 chlamydia-positive male and female participants of the CHARM cohort from the Baltimore area. All participants exhibited an antibody response to $C$. trachomatis purified EBs and at least one of the Pmps. While female CHARM participants had proportionally higher antibody levels to all Pmps compared to males, statistically significant gender differences were observed for 3 Pmps ( $\mathrm{rPmpC}, \mathrm{F}$ and $\mathrm{H})$. The higher antibody levels in females are consistent with previous reports of sex differences in antibody responses (reviewed in (25)). However, since $C$. trachomatis infection in men and women is diagnosed at different sites (the cervix in women and urethra in men), these findings are also consistent with the hypothesis that different Pmps may be expressed differentially in different anatomical sites and/or physiological environments.

Statistically significant differences in anti-Pmp antibody levels were not detected when comparing female CHARM participants with or without a positive clinical diagnosis for PID, indicating that the Pmp-specific antibody response is not significantly altered when the infection ascends to the upper genital tract compared to when it is limited to the lower genital tract. In turn, this suggests that the expressed Pmp profile of C. trachomatisinfected women is independent of the site of infection along the reproductive tract. Although Pmp-based differences were not observed, CHARM participants with a clinical

267 PID diagnosis were more likely to have high antibody levels against OmcB than those without. This is consistent with previous reports of OmcB being associated with CD8+ T 
medRxiv preprint doi: https://doi.org/10.1101/2021.05.25.21257614; this version posted May 27, 2021. The copyright holder for this preprint (which was not certified by peer review) is the author/funder, who has granted medRxiv a license to display the preprint in perpetuity.

All rights reserved. No reuse allowed without permission.

cell-mediated upper genital tract immunopathology (26). In contrast, antibody levels were almost identical for GroEL and MOMP, suggesting that these antigens are not associated with upper genital tract infection and PID, consistent with previous findings for GroEL (27) and MOMP (28). Our study failed to confirm the reported association of ClpP-specific antibodies with upper genital tract disease (19). However, this earlier study involved a different end point (tubal factor infertility) and a smaller cohort.

Overall, the observation of different antibody responses to specific Pmp subtypes in C. trachomatis-infected patients relative to gender and/or site of infection, while compatible with the hypothesized site-specific expression of Pmps in the context of infection, falls short of providing indisputable evidence for it, and does not lend confidence that these antigens are exploitable for sero-diagnosis. Multiple behavioral, immunological and structural factors have historically confounded or limited serologic analyses of chlamydial antigens for diagnostic purposes. For instance, potential cross-reactivity with orthologous antigens owing to Chlamydia pneumoniae (29) or Chlamydia psittaci (30) previous or concurrent infections, gender-associated differential immune responses (25), co-infection with other STIs, repeat infection with $C$. trachomatis or concurrent infection at multiple sites, as well as non-native structural features of recombinant antigens, are potential limitations of any approach toward reliable sero-diagnosis. Conversely, any statistically significant serologic difference that is detectable above the background 'noise' generated by these confounding factors and limitations should be exploitable as a diagnostic or prognostic tool. In this context, our findings that OmcB-specific serum antibody levels were elevated in women with a PID diagnosis suggests that this antigen is worthy of further study as a biomarker of upper genital tract disease. For instance, the 
medRxiv preprint doi: https://doi.org/10.1101/2021.05.25.21257614; this version posted May 27, 2021. The copyright holder for this preprint (which was not certified by peer review) is the author/funder, who has granted medRxiv a license to display the preprint in perpetuity.

All rights reserved. No reuse allowed without permission.

292 possibility of determining whether an asymptomatic C. trachomatis-infected woman is

293 likely to develop or already has subclinical upper genital tract pathology (silent PID; (31))

294 via a simple measurement of OmcB-specific antibody would be of great benefit to the

295 physician and ultimately to his/her patient. Although cross-reactive antibody responses

296 against C. pneumoniae OmcB have been reported (32), Gijsen et al. (33) also showed

297 that tubal pathology was more common in patients with both C. pneumoniae and $C$.

298 trachomatis antibodies compared to patients with antibodies against OmcB from only one

299 Chlamydia species, further strengthening a role for this well-conserved chlamydial protein

300 in eliciting pathology.

301

302

In conclusion, our expanded analysis of the observed Pmp-specific antibody profile

variation in C. trachomatis-infected men and women of the CHARM cohort may reflect

304 the hypothesized differential expression of different Pmp profiles as a prerequisite or in 305 response to infection of distinct urogenital sites. However other possibilities exist that 306 suggest that these antigens may be impractical to use as serologic biomarkers. Our study 307 also revealed an association between a high OmcB-specific serum antibody level and a 308 PID diagnosis. This finding corroborates previous studies (18) and indicates that this 309 protein may provide an exploitable discriminatory biomarker of disease severity during $C$. trachomatis infection. 
medRxiv preprint doi: https://doi.org/10.1101/2021.05.25.21257614; this version posted May 27, 2021. The copyright holder for this preprint (which was not certified by peer review) is the author/funder, who has granted medRxiv a license to display the preprint in perpetuity.

\section{REFERENCES}

312 1. https://www.cdc.gov/std/stats18/default.htm. Sexually Transmitted Disease Surveillance 2018: CDC; 2018.

2. Chlamydia. In: Services USDoHaH, ed. 2013 Sexually Transmitted Diseases Surveillance. Atlanta: Center for Disease Control and Prevention; 2013.

3. Ting LM, Hsia RC, Haidaris CG, Bavoil PM. Interaction of outer envelope proteins of Chlamydia psittaci GPIC with the HeLa cell surface. Infect Immun. 1995;63(9):3600-8.

4. Su H, Watkins NG, Zhang Y-X, Caldwell HD. Chlamydia trachomatis-host cell interactions: Role of the chlamydial major outer membrane protein as an adhesin. Infection \& Immunity. 1990;58:1017-25.

5. Moelleken K, Hegemann JH. The Chlamydia outer membrane protein OmcB is required for adhesion and exhibits biovar-specific differences in glycosaminoglycan binding. Mol Microbiol. 2008;67(2):403-19.

6. Crane DD, Carlson JH, Fischer ER, et al. Chlamydia trachomatis polymorphic membrane protein $D$ is a species-common pan-neutralizing antigen. Proc Natl

7. Baehr W, Zhang Y-X, Joseph T, et al. Mapping antigenic domains expressed by Chlamydia trachomatis major outer membrane protein genes. Proceedings of the National Academy of Science,U.S.A. 1988;85:4000-4.

8. Carrasco JA, Tan C, Rank RG, Hsia RC, Bavoil PM. Altered developmental expression of polymorphic membrane proteins in penicillin-stressed Chlamydia trachomatis. Cell Microbiol. 2011;13(7):1014-25. 
medRxiv preprint doi: https://doi.org/10.1101/2021.05.25.21257614; this version posted May 27, 2021. The copyright holder for this preprint (which was not certified by peer review) is the author/funder, who has granted medRxiv a license to display the preprint in perpetuity. All rights reserved. No reuse allowed without permission.

9. Fadel S, Eley A. Chlamydia trachomatis OmcB protein is a surface-exposed glycosaminoglycan-dependent adhesin. J Med Microbiol. 2007;56(Pt 1):15-22.

10. Su H, Watkins NG, Zhang YX, Caldwell HD. Chlamydia trachomatis-host cell interactions: role of the chlamydial major outer membrane protein as an adhesin. Infect Immun. 1990;58(4):1017-25.

11. Stephens RS, Kalman S, Lammel C, et al. Genome sequence of an obligate intracellular pathogen of humans: Chlamydia trachomatis. Science. 1998;282(5389):754-9.

12. Gomes JP, Nunes A, Bruno WJ, Borrego MJ, Florindo C, Dean D. Polymorphisms in the nine polymorphic membrane proteins of Chlamydia trachomatis across all serovars: evidence for serovar Da recombination and correlation with tissue tropism. J Bacteriol. 2006;188(1):275-86.

13. Paes W, Dowle A, Coldwell J, Leech A, Ganderton T, Brzozowski A. The Chlamydia trachomatis PmpD adhesin forms higher order structures through disulphide-mediated covalent interactions. PLoS One. 2018;13(6):e0198662.

14. Tan C, Hsia RC, Shou H, Carrasco JA, Rank RG, Bavoil PM. Variable expression of surface-exposed polymorphic membrane proteins in in vitro-grown Chlamydia trachomatis. Cell Microbiol. 2010;12(2):174-87.

15. Tan C, Hsia RC, Shou H, et al. Chlamydia trachomatis-infected patients display variable antibody profiles against the nine-member polymorphic membrane protein family. Infect Immun. 2009;77(8):3218-26.

16. Taylor BD, Darville T, Tan C, Bavoil PM, Ness RB, Haggerty CL. The role of Chlamydia trachomatis polymorphic membrane proteins in inflammation and 
medRxiv preprint doi: https://doi.org/10.1101/2021.05.25.21257614; this version posted May 27, 2021. The copyright holder for this preprint (which was not certified by peer review) is the author/funder, who has granted medRxiv a license to display the preprint in perpetuity. All rights reserved. No reuse allowed without permission.

sequelae among women with pelvic inflammatory disease. Infect Dis Obstet Gynecol. 2011;2011:989762.

17. Peeling RW, Kimani J, Plummer F, et al. Antibody to Hsp60 predicts an increased risk for chlamydial pelvic inflammatory disease. J.Infect.Dis. 1997;175:1153-8.

18. Wagar EA, Schachter J, Bavoil PM, Stephens RS. Differential human serologic response to two 60,000 molecular weight Chlamydia trachomatis antigens. J.Infect.Dis. 1990;162:922-7.

19. Rodgers AK, Wang J, Zhang $\mathrm{Y}$, et al. Association of tubal factor infertility with elevated antibodies to Chlamydia trachomatis caseinolytic protease P. Am J Obstet Gynecol. 2010;203(5):494 e7- e14.

20. Mark KS, Brotman RM, Martinez-Greiwe S, Terplan M, Bavoil P, Ravel J. Chlamydia in adolescent/adult reproductive management trial study (CHARM): Clinical core protocol. Contemp Clin Trials Commun. 2019;16:100414.

21. https://www.cdc.gov/std/pid/stdfact-pid-detailed.htm. Pelvic Inflammatory Disease: CDC; 2020.

22. Mahony JB, Schachter J, Chernesky MA. Detection of antichlamydial immunoglobulin $G$ and $M$ antibodies by enzyme linked immunosorbent assay. Journal of Clinical Microbiology. 1983;18:270-5.

23. Frikha-Gargouri O, Gdoura R, Znazen A, et al. Evaluation of an in silico predicted specific and immunogenic antigen from the OmcB protein for the serodiagnosis of Chlamydia trachomatis infections. BMC Microbiol. 2008;8:217. 
medRxiv preprint doi: https://doi.org/10.1101/2021.05.25.21257614; this version posted May 27, 2021. The copyright holder for this preprint (which was not certified by peer review) is the author/funder, who has granted medRxiv a license to display the preprint in perpetuity.

378 24. Amsel R, Totten PA, Spiegel CA, Chen KC, Eschenbach D, Holmes KK. Nonspecific vaginitis. Diagnostic criteria and microbial and epidemiologic associations. Am J Med. 1983;74(1):14-22.

381

382

383

384

385 386

25. Klein SL, Flanagan KL. Sex differences in immune responses. Nat Rev Immunol. 2016;16(10):626-38.

26. Vlcek KR, Li W, Manam S, et al. The contribution of Chlamydia-specific CD8(+) T cells to upper genital tract pathology. Immunol Cell Biol. 2016;94(2):208-12.

27. Ness RB, Soper DE, Richter HE, et al. Chlamydia antibodies, chlamydia heat shock protein, and adverse sequelae after pelvic inflammatory disease: the PID Evaluation and Clinical Health (PEACH) Study. Sex Transm Dis. 2008;35(2):12935.

28. Stothard DR, Boguslawski G, Jones RB. Phylogenetic analysis of the Chlamydia trachomatis major outer membrane protein and examination of potential pathogenic determinants. Infect Immun. 1998;66(8):3618-25.

29. Baud D, Regan L, Greub G. Comparison of five commercial serological tests for the detection of anti-Chlamydia trachomatis antibodies. Eur J Clin Microbiol Infect Dis. 2010;29(6):669-75.

30. Dumke R, Schnee C, Pletz MW, et al. Mycoplasma pneumoniae and Chlamydia spp. infection in community-acquired pneumonia, Germany, 2011-2012. Emerg Infect Dis. 2015;21(3):426-34.

31. Wiesenfeld HC, Sweet RL, Ness RB, Krohn MA, Amortegui AJ, Hillier SL. Comparison of acute and subclinical pelvic inflammatory disease. Sex Transm Dis. $2005 ; 32(7): 400-5$. 
medRxiv preprint doi: https://doi.org/10.1101/2021.05.25.21257614; this version posted May 27, 2021. The copyright holder for this preprint (which was not certified by peer review) is the author/funder, who has granted medRxiv a license to display the preprint in perpetuity. All rights reserved. No reuse allowed without permission.

401 32. Bas S, Muzzin P, Vischer TL. Chlamydia trachomatis serology: diagnostic value of 402 outer membrane protein 2 compared with that of other antigens. J Clin Microbiol.

404

33. Gijsen AP, Land JA, Goossens VJ, Leffers P, Bruggeman CA, Evers JL.

405 Chlamydia pneumoniae and screening for tubal factor subfertility. Hum Reprod.

406 2001;16(3):487-91. 
medRxiv preprint doi: https://doi.org/10.1101/2021.05.25.21257614; this version posted May 27, 2021. The copyright holder for this preprint (which was not certified by peer review) is the author/funder, who has granted medRxiv a license to display the preprint in perpetuity.

Figure legends

FIGURE 1: Schematic representation of the Pmp proteins and recombinant polypeptides used in this study. Structural features of Pmps are shown; Predicted signal peptide using Signal 4.0 software (yellow), passenger domain (green), GGA[I/L/V]

412 (black bars) and FXXN (orange bars) tetrapeptide repeats and autotransporter domain 413 (red). Recombinant Pmp derivatives based on predicted hydrophilic and antigenic 414 domains located within the Pmp passenger domain, expressed in GST•tag pGEX-2t 415 vector (GE Healthcare Biosciences) are shown in light purple (G-rPmpA-F1) and purple 416 (G-rPmpA-F2, G-rPmpB-F1 and G-rPmp-F2). Passenger domain recombinant proteins expressed as inclusion bodies in His॰tag pET30 (a or b) are in blue (H-rPmp(C to I)-N).

FIGURE 2: High cut-off index antibodies associated with a PID diagnosis. Sera from 153 female CHARM participants were analyzed by ELISA. Odds ratios (ORs) for PID

421 positivity when a patient is in the second (black) or third (grey) tertile, compared to the first 422 tertile are shown. The OR (95\% confidence interval) was greater than 1 for G-rOmcB in 423 both tertiles and $\mathrm{H}-\mathrm{rOmcB}$ in the second tertile $\left({ }^{*} \mathrm{p}<0.05\right)$ suggesting that high antibody 424 cut-off indexes for this antigen were significantly associated with PID. Results for $\mathrm{H}$ 425 rPmpl-N second tertile were borderline significant $(\ddagger p=0.075)$. 
medRxiv preprint doi: https://doi.org/10.1101/2021.05.25.21257614; this version posted May 27, 2021. The copyright holder for this preprint (which was not certified by peer review) is the author/funder, who has granted medRxiv a license to display the preprint in perpetuity.

Supplemental Digital Content 1.pptx:

Supplemental Digital Content 1. Table S1, which lists the characteristics and purification conditions of the recombinant polypeptides.

Supplemental Digital Content 1. Figure S1, showing Expression and purification of of all recombinant proteins; 1: G-rPmpA-F2, 2: G-rPmpB-F1, 3: G-rPmpB-F2, 4 to 10: HrPmp(C to I)-N, 11: G-rClpP, 12: G-rHsp60, 13: G-rMOMP, 14: G-rOmcB, 15: H-rOmcB and 16: GST only. B) Immunoblots. Primary antibodies: guinea pig anti-Pmp A to I (lanes 1-10), mouse anti-ClpP (provided by Dr. Guangming Zhong) (lane 11), rabbit anti-GroEL (lane 12) and anti-OmcB (lanes 14-15) and goat anti-MOMP (LifeSpan BioSciences) (lane

13) and anti-GST (GE Healthcare Bio-Sciences) (lane 16); secondary antibodies: Alkaline (Sigma-Aldrich). Membranes were revealed with fluorescent alkaline phosphatase substrate ECF (GE Healthcare Biosciences). *Apparent molecular weights of protein bands are listed in Table S1. 
medRxiv preprint doi: https://doi.org/10.1101/2021.05.25.21257614; this version posted May 27, 2021. The copyright holder for this preprint (which was not certified by peer review) is the author/funder, who has granted medRxiv a license to display the preprint in perpetuity. All rights reserved. No reuse allowed without permission.

452 between the ELISA results obtained with these 2 proteins was statistical significant $453(0.7462, p<0.001)$.

454

455 Supplemental Digital Content 1. Table S3, showing the ELISA results, sensitivity and 456 coefficient variation

457

458 Supplemental Digital Content 1. Table S4 listing tertiles for females only $(n=153)$

459

460 
medRxiv preprint doi: https://doi.org/10.1101/2021.05.25.21257614; this version posted May 27, 2021. The copyright holder for this preprint (which was not certified by peer review) is the author/funder, who has granted medRxiv a license to display the preprint in perpetuity.

All rights reserved. No reuse allowed without permission.

Figure 1: Marques et al.

Pmp A

\begin{tabular}{l|l|l|l|}
\hline G-rPmpA-F1 & & \\
& G-rPmpA-F2 & \\
& & Pmp B
\end{tabular}

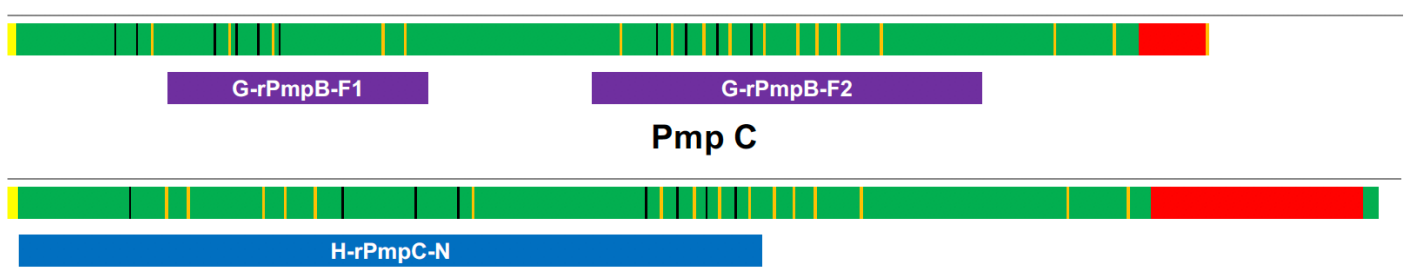

Pmp D

$\begin{array}{r}\hline \text { H-rPmpD-N } \\ \text { Pmp E } \\ \hline\end{array}$
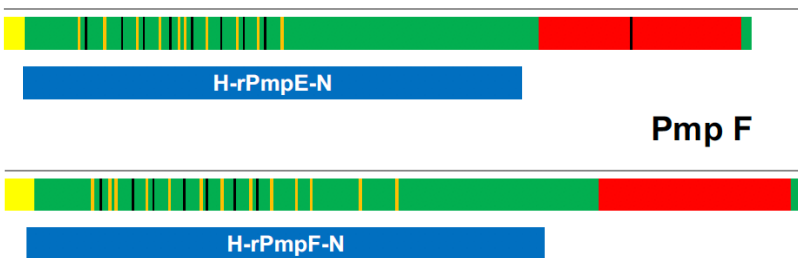

Pmp G

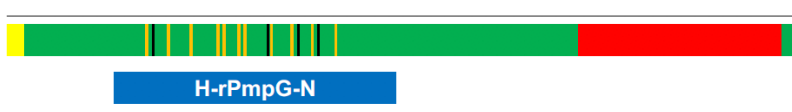

Pmp H

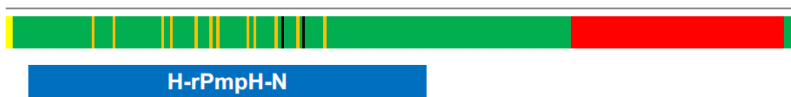

Pmp I 
medRxiv preprint doi: https://doi.org/10.1101/2021.05.25.21257614; this version posted May 27, 2021. The copyright holder for this preprint (which was not certified by peer review) is the author/funder, who has granted medRxiv a license to display the preprint in perpetuity. All rights reserved. No reuse allowed without permission.

Figure 2. Marques et al.

G-rPmpA-F2
G-rPmpB-F1
G-rPmpB-F2
H-rPmpC-N
H-rPmpD-N
H-rPmpE-N
H-rPmpF-N
H-rPmpG-N
H-rPmpH-N
H-rPmpl-N
G-rClpP
G-rHsp60
G-rMOMP
G-rOmcB
H-rOmcB
Purified-EBs

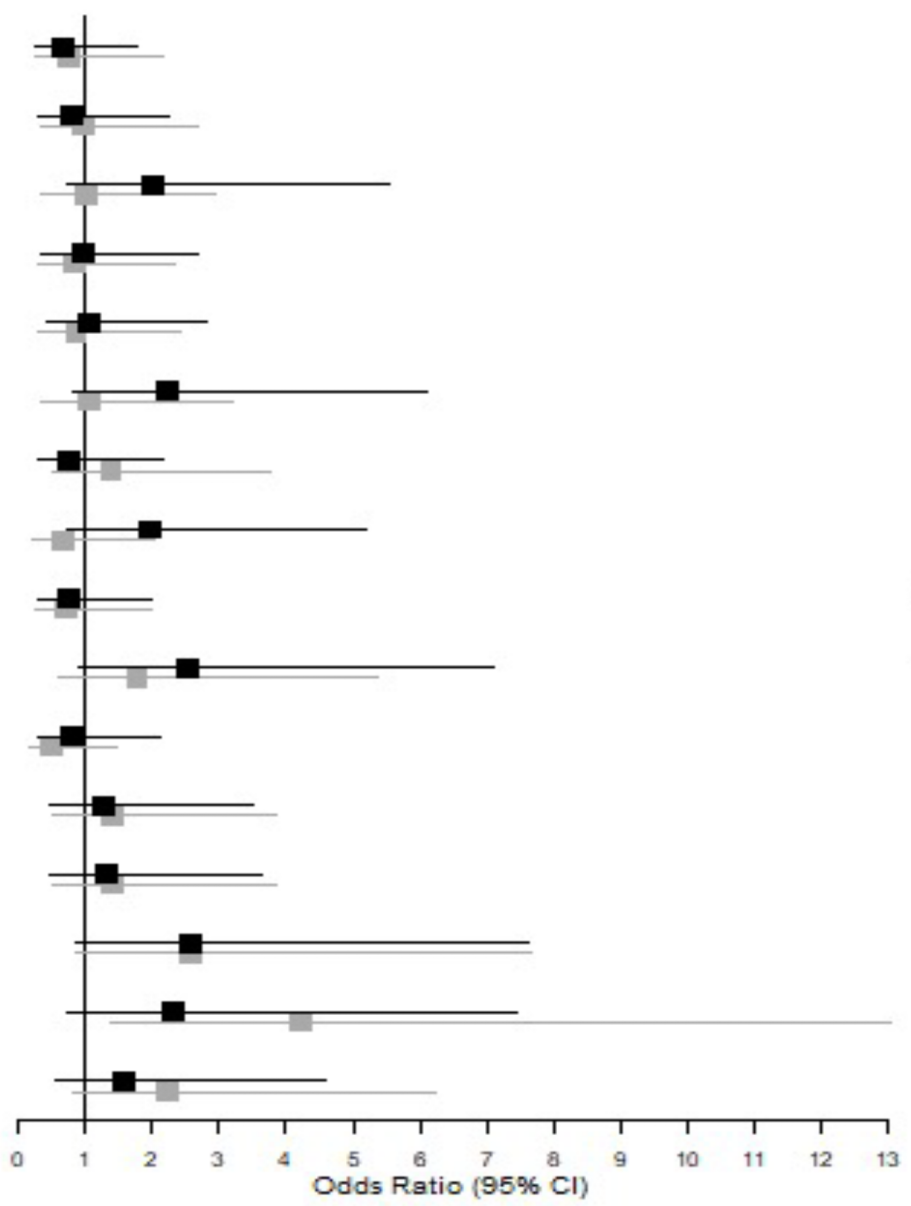

Second tertile Third tertile 
medRxiv preprint doi: https://doi.org/10.1101/2021.05.25.21257614; this version posted May 27, 2021. The copyright holder for this preprint (which was not certified by peer review) is the author/funder, who has granted medRxiv a license to display the preprint in perpetuity.

TABLES:

TABLE 1: Demographics and sexual behavior compared between genders

\begin{tabular}{lllll}
\hline & Overall & Male N=120 (\%) & Female N=145 (\%) & P-value $^{\text {a }}$ \\
\hline Age, median (IQR) & $19.5(17-21)$ & $20.2(18-22)$ & $18.9(17-21)$ & $\mathbf{0 . 0 0 4 7}^{\mathbf{b}}$ \\
\hline Age groups & & & $\mathbf{0 . 0 0 1}$ \\
\hline $\mathbf{2 0}$ years old & $150(56.60)$ & $55(45.83)$ & $95(65.52)$ & \\
\hline $\mathbf{2 0}$ years old & $115(43.40)$ & $65(54.17)$ & $50(34.48)$ & \\
& & &
\end{tabular}

\section{Sexual history}

\begin{tabular}{llll}
\hline Age of sexual debut & & \\
\hline$<13$ years old & $223(84.15)$ & $93(77.50)$ & $130(89.66)$ \\
& $42(15.85)$ & $27(22.50)$ & $15(10.34)$
\end{tabular}

\begin{tabular}{lllll}
\hline Sexual partners lifetime & & & $<0.001$ \\
\hline$<6$ partners & $94(35.47)$ & $26(21.67)$ & $68(46.90)$ & \\
\hline 6+ partners & $171(64.53)$ & $94(78.33)$ & $77(53.10)$ & \\
\hline Oral sex & $233(87.92)$ & $109(90.83)$ & $124(85.52)$ & 0.186 \\
\hline Anal sex & $79(29.81)$ & $41(34.17)$ & $38(26.21)$ & 0.159 \\
\hline Condom use in past 3 months & $32(11.99)$ & $21(17.50)$ & $11(7.59)$ & $\mathbf{0 . 0 1 4}$
\end{tabular}

Self-reported STI and reproductive health history

\begin{tabular}{|c|c|c|c|c|}
\hline Bacterial STIC & $206(77.74)$ & $88(73.33)$ & $118(81.38)$ & 0.117 \\
\hline Viral STI ${ }^{d}$ & $27(10.19)$ & $9(7.50)$ & $18(12.41)$ & 0.188 \\
\hline Trichomonas vaginalis & $\mathrm{N} / \mathrm{A}^{\mathrm{e}}$ & N/A & $28(19.31)$ & N/A \\
\hline BV & N/A & N/A & $15(10.34)$ & N/A \\
\hline PID & N/A & $\mathrm{N} / \mathrm{A}$ & $6(4.14)$ & N/A \\
\hline \multicolumn{5}{|c|}{ Physician assessment $^{f}$} \\
\hline PID & N/A & N/A & $33(22.76)$ & N/A \\
\hline \multicolumn{5}{|c|}{ STI Diagnostic Laboratory tests (current) } \\
\hline HIV & $18(6.79)$ & $8(6.67)$ & $10(6.90)$ & 0.941 \\
\hline
\end{tabular}


medRxiv preprint doi: https://doi.org/10.1101/2021.05.25.21257614; this version posted May 27, 2021. The copyright holder for this preprint (which was not certified by peer review) is the author/funder, who has granted medRxiv a license to display the preprint in perpetuity. All rights reserved. No reuse allowed without permission.

\begin{tabular}{lcccc}
\hline RPR/ syphilis & $2(0.75)$ & $1(0.83)$ & $1(0.69)$ & 0.893 \\
\hline GC/ gonorrhoea & $20(7.55)$ & $10(8.33)$ & $10(6.90)$ & 0.659
\end{tabular}

ap-values from chi-square, unless otherwise indicated

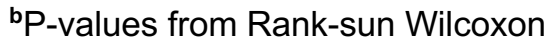

'gonorrhoea, chlamydia and syphilis

dHPV, Herpes and HIV

N/A, not applicable, diagnosed in women only

PID assessment was performed by a physician following CDC criteria 
medRxiv preprint doi: https://doi.org/10.1101/2021.05.25.21257614; this version posted May 27, 2021. The copyright holder for this preprint (which was not certified by peer review) is the author/funder, who has granted medRxiv a license to display the preprint in perpetuity. All rights reserved. No reuse allowed without permission.

TABLE 2: Association of demographic, biological and sexual behaviors in 33 women with a PID diagnosis among the 145 women in the study

\begin{tabular}{|c|c|c|c|c|c|}
\hline & \multirow[b]{2}{*}{ Overall } & \multicolumn{2}{|c|}{ Unadjusted analysis } & \multicolumn{2}{|c|}{ Adjusted analysis } \\
\hline & & Odd ratio $(95 \% \mathrm{Cl})$ & p-value & Odd ratio $(95 \% \mathrm{Cl})$ & p-value ${ }^{a}$ \\
\hline Age groups & & & 0.796 & & 0.523 \\
\hline$\leq 20$ years old & $95(65.52)$ & 1 & & 1 & \\
\hline$>20$ years old & $50(34.48)$ & $1.11(0.50,2.50)$ & & $0.75(0.35,1.83)$ & \\
\hline \multicolumn{6}{|c|}{ Sexual history } \\
\hline Age of sexual debut & & & 0.135 & & 0.326 \\
\hline$<13$ years old & $107(73.79)$ & $1.89(0.82,4.35)$ & & $1.60(0.63,4.05)$ & \\
\hline $13+$ years old & $38(26.21)$ & 1 & & 1 & \\
\hline Sexual partners & & & 0.079 & & 0.274 \\
\hline \multicolumn{6}{|l|}{ lifetime } \\
\hline$<6$ partners & $68(46.90)$ & 1 & & 1 & \\
\hline $6+$ partners & $77(53.10)$ & $2.07(0.92,4.67)$ & & $1.64(0.674 .00)$ & \\
\hline Receptive oral sex & $119(82.07)$ & $2.58(0.72,9.22)$ & 0.144 & $2.00(1.00,1.00)$ & 0.596 \\
\hline ever (vs. never) & & & & & \\
\hline Anal sex ever & $38(26.21)$ & $1.07(0.45,2.57)$ & 0.874 & $0.89(0.36,2.24)$ & 0.808 \\
\hline (vs. never) & & & & & \\
\hline No condom use in past & $134(92.41)$ & $N / A^{b}$ & N/A & $N / A^{b}$ & $\mathrm{~N} / \mathrm{A}$ \\
\hline
\end{tabular}

Self-reported prior STI

\begin{tabular}{lccccc}
\hline Bacterial STI $^{\mathbf{c}}$ & $118(81.38)$ & $2.73(0.77,9.71)$ & 0.121 & $2.19(0.59,8.22)$ & 0.244 \\
\hline Viral STI $^{\mathbf{d}}$ & $18(12.41)$ & $0.97(0.29,3.16)$ & 0.954 & $0.54(0.14,2.09)$ & 0.373 \\
\hline Trichomonas vaginalis & $28(19.31)$ & $2.79(1.15,6.80)$ & $\mathbf{0 . 0 2 3}$ & $2.36(0.89,6.25)$ & $\mathbf{0 . 0 8 3}$ \\
\hline BV & $15(10.34)$ & $2.54(0.83,7.77)$ & 0.101 & $2.19(0.68,7.04)$ & 0.191 \\
\hline PID & $6(4.14)$ & $19.82(2.23,176.52)$ & $\mathbf{0 . 0 0 7}$ & - &
\end{tabular}


medRxiv preprint doi: https://doi.org/10.1101/2021.05.25.21257614; this version posted May 27, 2021. The copyright holder for this preprint (which was not certified by peer review) is the author/funder, who has granted medRxiv a license to display the preprint in perpetuity. All rights reserved. No reuse allowed without permission.

\section{STI Diagnostic Laboratory tests (current) ${ }^{c}$}

\begin{tabular}{lccccc}
\hline HIV & $10(6.90)$ & $0.36(0.04,2.93)$ & 0.338 & $0.25(0.03,2.32)$ & 0.223 \\
\hline GC/ gonorrhea & $10(6.90)$ & $0.84(0.17,4.16)$ & 0.829 & $1.00(0.19,5.20)$ & 0.998
\end{tabular}

aP-values from logistic regression

${ }^{b}$ None of the female participants positive for PID used condoms

'gonorrhoea and chlamydia (syphilis was not analyzed because it was only detected in 1 female)

${ }^{\mathrm{d} H P V}$, Herpes and HIV 
medRxiv preprint doi: https://doi.org/10.1101/2021.05.25.21257614; this version posted May 27, 2021. The copyright holder for this preprint (which was not certified by peer review) is the author/funder, who has granted medRxiv a license to display the preprint in perpetuity. All rights reserved. No reuse allowed without permission.

TABLE 3: Chlamydia antigenic biomarkers compared between genders (categorized by tertiles)

\begin{tabular}{|c|c|c|c|c|}
\hline & Overall & Male $\mathrm{N}=122(\%)$ & Female $\mathrm{N}=145(\%)$ & P-value $^{a}$ \\
\hline G-rPmpA-F2 & & & & 0.068 \\
\hline$<0.41$ & $89(33.58)$ & $45(37.50)$ & $44(30.34)$ & \\
\hline $0.41-1.04$ & $88(33.21)$ & $44(36.67)$ & $44(30.34)$ & \\
\hline$>1.04$ & $88(33.21)$ & $31(25.83)$ & $57(39.31)$ & \\
\hline G-rPmpB-F1 & & & & 0.586 \\
\hline$<0.28$ & $89(33.58)$ & $43(35.83)$ & $46(31.72)$ & \\
\hline $0.28-0.69$ & $88(33.21)$ & $41(34.17)$ & $47(32.41)$ & \\
\hline$>0.69$ & $88(33.21)$ & $36(30.00)$ & $52(35.86)$ & \\
\hline G-rPmpB-F2 & & & & 0.417 \\
\hline$<0.55$ & $90(33.96)$ & $42(35.00)$ & $48(33.10)$ & \\
\hline $0.55-2.40$ & $87(32.83)$ & $43(35.83)$ & $44(30.34)$ & \\
\hline$>2.40$ & $88(33.21)$ & $35(29.17)$ & $53(36.55)$ & \\
\hline H-rPmpC-N & & & & 0.001 \\
\hline$<8.75$ & 89 (33.58) & $54(45.00)$ & $35(24.14)$ & \\
\hline $8.75-20.47$ & $88(33.21)$ & $35(29.17)$ & $53(36.55)$ & \\
\hline$>20.47$ & $88(33.21)$ & $31(25.83)$ & $57(39.31)$ & \\
\hline H-rPmpD-N & & & & 0.195 \\
\hline$<1.88$ & $89(33.58)$ & $47(39.17)$ & $42(28.97)$ & \\
\hline $1.88-4.10$ & $88(33.21)$ & $38(31.67)$ & $50(34.48)$ & \\
\hline$>4.10$ & $88(33.21)$ & $35(29.17)$ & $53(36.55)$ & \\
\hline H-rPmpE-N & & & & 0.063 \\
\hline$<6.13$ & $89(33.58)$ & $46(38.33)$ & $43(29.66)$ & \\
\hline $6.13-14.94$ & $88(33.21)$ & $43(35.83)$ & $45(31.03)$ & \\
\hline$>14.94$ & $88(33.21)$ & $31(25.83)$ & $57(39.31)$ & \\
\hline H-rPmpF-N & & & & 0.020 \\
\hline
\end{tabular}


medRxiv preprint doi: https://doi.org/10.1101/2021.05.25.21257614; this version posted May 27, 2021. The copyright holder for this preprint (which was not certified by peer review) is the author/funder, who has granted medRxiv a license to display the preprint in perpetuity. All rights reserved. No reuse allowed without permission.

\begin{tabular}{|c|c|c|c|c|}
\hline$<5.52$ & $89(33.58)$ & $51(42.50)$ & $38(26.21)$ & \\
\hline $5.52-19.85$ & $88(33.21)$ & $34(28.33)$ & $54(37.24)$ & \\
\hline$>19.85$ & $88(33.21)$ & $35(29.17)$ & $53(36.55)$ & \\
\hline H-rPmpG-N & & & & 0.199 \\
\hline$<0.79$ & 89 (33.58) & $44(36.67)$ & $45(31.03)$ & \\
\hline $0.79-3.69$ & $88(33.21)$ & $43(35.83)$ & $45(31.03)$ & \\
\hline$>3.69$ & $88(33.21)$ & $33(27.50)$ & 55 (37.93) & \\
\hline H-rPmpH-N & & & & 0.018 \\
\hline$<1.93$ & $89(33.58)$ & $46(38.33)$ & $43(29.66)$ & \\
\hline $1.93-5.17$ & $88(33.21)$ & $45(37.50)$ & $43(29.66)$ & \\
\hline$>5.17$ & $88(33.21)$ & $29(24.17)$ & 59 (40.69) & \\
\hline H-rPmpl-N & & & & 0.105 \\
\hline$<4.19$ & 89 (33.58) & $46(38.33)$ & $43(29.66)$ & \\
\hline $4.19-10.68$ & $88(33.21)$ & $42(35.00)$ & $46(31.72)$ & \\
\hline$>10.68$ & $88(33.21)$ & $32(26.67)$ & $56(38.62)$ & \\
\hline G-rClpP & & & & 0.709 \\
\hline$<0.68$ & 89 (33.58) & $39(32.50)$ & $50(34.48)$ & \\
\hline $0.68-2.08$ & $88(33.21)$ & 38 (31.67) & $50(34.48)$ & \\
\hline$>2.08$ & $88(33.21)$ & $43(35.83)$ & $45(31.03)$ & \\
\hline G-rGroEL & & & & 0.952 \\
\hline$<4.11$ & $89(33.58)$ & $40(33.33)$ & 49 (33.79) & \\
\hline $4.11-13.58$ & $88(33.21)$ & $39(32.50)$ & 49 (33.79) & \\
\hline$>13.58$ & $88(33.21)$ & $41(34.17)$ & $47(32.41)$ & \\
\hline G-rMOMP & & & & 0.011 \\
\hline$<1.64$ & $89(33.58)$ & $51(42.50)$ & $38(26.21)$ & \\
\hline $1.64-4.61$ & $88(33.21)$ & $32(25.83)$ & $57(39.31)$ & \\
\hline$>4.61$ & $88(33.21)$ & 38 (31.67) & $50(34.48)$ & \\
\hline
\end{tabular}


medRxiv preprint doi: https://doi.org/10.1101/2021.05.25.21257614; this version posted May 27, 2021. The copyright holder for this preprint (which was not certified by peer review) is the author/funder, who has granted medRxiv a license to display the preprint in perpetuity. All rights reserved. No reuse allowed without permission.

\begin{tabular}{lcccc}
\hline G-rOmcB & & & 0.830 \\
\hline$<1.94$ & $89(33.58)$ & $40(33.33)$ & $49(33.79)$ & \\
\hline $1.94-4.44$ & $88(33.21)$ & $42(35.00)$ & $46(31.72)$ & \\
\hline$>4.44$ & $88(33.21)$ & $38(31.67)$ & $50(34.48)$ & 0.835 \\
\hline H-rOmcB & & & & \\
\hline$<7.00$ & $89(33.58)$ & $38(31.67)$ & $41(35.17)$ & \\
\hline $7.00-24.83$ & $88(33.21)$ & $41(34.17)$ & $47(32.41)$ & 0.308 \\
\hline$>24.83$ & $88(33.21)$ & $41(34.17)$ & $47.41)$ & \\
\hline Ct purified EBs & & & & \\
\hline$<1.96$ & $89(33.58)$ & $43(35.83)$ & $46(31.72)$ & \\
\hline $\mathbf{1 . 9 6 - 5 . 2 2}$ & $88(33.21)$ & $43(35.83)$ & $45(31.03)$ & \\
\hline$>5.22$ & $88(33.21)$ & $34(28.33)$ & $54(37.24)$ & \\
\hline
\end{tabular}

ap-values from chi-square

${ }^{\mathrm{b}}$ Chlamydia trachomatis serovar E purified EBs 
medRxiv preprint doi: https://doi.org/10.1101/2021.05.25.21257614; this version posted May 27, 2021. The copyright holder for this preprint (which was not certified by peer review) is the author/funder, who has granted medRxiv a license to display the preprint in perpetuity.

All rights reserved. No reuse allowed without permission.

TABLE 4: Assessing associations between the levels of the factors (in tertiles) associated with PID diagnosis (tertiles calculated only for females, described on Table S4)

\begin{tabular}{|c|c|c|c|c|}
\hline \multirow{2}{*}{ Biomarkers } & \multicolumn{2}{|l|}{ second vs first } & \multicolumn{2}{|l|}{ third vs first } \\
\hline & Unadjusted Odds Ratio $(95 \% \mathrm{Cl})$ & p-value & Unadjusted Odds Ratio $(95 \% \mathrm{Cl})$ & $p$-value ${ }^{a}$ \\
\hline G-rPmpA-F2 & $0.66(0.26-1.67)$ & 0.379 & $0.58(0.22-1.50)$ & 0.258 \\
\hline G-rPmpB-F1 & $0.64(0.24-1.67)$ & 0.362 & $0.82(0.33-2.08)$ & 0.680 \\
\hline G-rPmpB-F2 & $1.83(0.70-4.75)$ & 0.214 & $1.17(0.43-3.19)$ & 0.760 \\
\hline H-rPmpC-N & $0.92(0.36-2.34)$ & 0.855 & $0.81(0.31-2.11)$ & 0.667 \\
\hline H-rPmpD-N & $1.03(0.41-2.59)$ & 0.954 & $0.71(0.27-1.89)$ & 0.494 \\
\hline H-rPmpE-N & $1.77(0.70-4.47)$ & 0.225 & $0.78(0.28-2.18)$ & 0.636 \\
\hline H-rPmpF-N & $0.71(0.27-1.89)$ & 0.494 & $1.03(0.41-2.59)$ & 0.954 \\
\hline H-rPmpG-N & $1.57(0.63-3.89)$ & 0.330 & $0.59(0.21-1.68)$ & 0.322 \\
\hline H-rPmpH-N & $0.66(0.26-1.67)$ & 0.379 & $0.58(0.22-1.50)$ & 0.258 \\
\hline H-rPmpl-N & $2.33(0.88-6.16)$ & 0.088 & $1.35(0.48-3.77)$ & 0.569 \\
\hline G-ClpP & $0.92(0.37-2.29)$ & 0.863 & $0.55(0.21-1.49)$ & 0.242 \\
\hline G-rGroEL & $1.48(0.56-3.93)$ & 0.429 & $1.48(0.56-3.93)$ & 0.429 \\
\hline G-rMOMP & $1.48(0.56-3.93)$ & 0.429 & $1.48(0.56-3.93)$ & 0.429 \\
\hline G-rOmcB & $2.95(1.03-8.49)$ & 0.045 & $2.66(0.92-7.72)$ & 0.072 \\
\hline H-rOmcB & $2.62(0.83-8.21)$ & 0.099 & $4.83(1.61-14.47)$ & 0.005 \\
\hline \multirow[t]{3}{*}{$\mathrm{Ct}_{\text {purified }} \mathrm{EBs}^{\mathrm{b}}$} & $1.52(0.55-4.20)$ & 0.415 & $2.11(0.79-5.63)$ & 0.135 \\
\hline & second vs first & & third vs first & \\
\hline & Adjusted $^{\mathrm{c}}$ Odds Ratio $(95 \% \mathrm{Cl})$ & p-value & Adjusted $^{\mathrm{c}}$ Odds Ratio $(95 \% \mathrm{Cl})$ & p-value \\
\hline G-rPmpA-F2 & $0.68(0.26-1.79)$ & 0.432 & $0.76(0.27-2.14)$ & 0.606 \\
\hline G-rPmpB-F1 & $0.80(0.28-2.25)$ & 0.668 & $0.98(0.35-2.69)$ & 0.962 \\
\hline G-rPmpB-F2 & $2.00(0.72-5.52)$ & 0.181 & $1.01(0.35-2.92)$ & 0.983 \\
\hline H-rPmpC-N & $0.98(0.36-2.66)$ & 0.974 & $0.85(0.31-2.33)$ & 0.752 \\
\hline
\end{tabular}




\begin{tabular}{cllll} 
H-rPmpD-N & $1.07(0.41-2.81)$ & 0.892 & $0.86(0.31-2.40)$ & 0.774 \\
H-rPmpE-N & $2.21(0.80-6.10)$ & 0.128 & $1.06(0.35-3.19)$ & 0.922 \\
H-rPmpF-N & $0.77(0.28-2.16)$ & 0.622 & $1.38(0.51-3.75)$ & 0.529 \\
H-rPmpG-N & $1.96(0.74-5.17)$ & 0.175 & $0.68(0.22-2.03)$ & 0.486 \\
H-rPmpH-N & $0.74(0.28-1.98)$ & 0.551 & $0.71(0.25-1.99)$ & 0.510 \\
H-rPmpl-N & $2.52(0.89-7.11)$ & $\mathbf{0 . 0 8 1}$ & $1.77(0.59-5.36)$ & 0.310 \\
G-ClpP & $0.80(0.31-2.11)$ & 0.657 & $0.51(0.18-1.45)$ & 0.208 \\
G-rGroEL & $1.28(0.47-3.49)$ & 0.634 & $1.40(0.51-3.87)$ & 0.517 \\
G-rMOMP & $1.32(0.48-3.63)$ & 0.592 & $1.39(0.50-3.85)$ & 0.529 \\
G-rOmcB & $2.58(0.87-7.63)$ & $\mathbf{0 . 0 8 7}$ & $2.56(0.86-7.65)$ & $\mathbf{0 . 0 9 1}$ \\
H-rOmcB & $2.31(0.72-7.46)$ & 0.160 & $4.22(1.37-13.01)$ & $\mathbf{0 . 0 1 2}$ \\
Ct purified EBs & $1.59(0.56-4.57)$ & 0.385 & $2.23(0.80-6.24)$ & 0.127 \\
\hline
\end{tabular}

a P-values from logistic regression

${ }^{\mathrm{b}}$ Chlamydia trachomatis serovar E purified EBs

${ }^{\mathrm{c}}$ Adjusted for age, sexual partners ever, Trichomonas vaginalis and Bacterial Vaginosis (BV) 